\title{
Comment on the Modigliani-Miller Propositions
}

\author{
Stephen A. Ross
}

The Journal of Economic Perspectives, Vol. 2, No. 4. (Autumn, 1988), pp. 127-133.

Stable URL:

http://links.jstor.org/sici?sici=0895-3309\%28198823\%292\%3A4\%3C127\%3ACOTMP\%3E2.0.CO\%3B2-2

The Journal of Economic Perspectives is currently published by American Economic Association.

Your use of the JSTOR archive indicates your acceptance of JSTOR's Terms and Conditions of Use, available at

http://www.jstor.org/about/terms.html. JSTOR's Terms and Conditions of Use provides, in part, that unless you have obtained prior permission, you may not download an entire issue of a journal or multiple copies of articles, and you may use content in the JSTOR archive only for your personal, non-commercial use.

Please contact the publisher regarding any further use of this work. Publisher contact information may be obtained at http://www.jstor.org/journals/aea.html.

Each copy of any part of a JSTOR transmission must contain the same copyright notice that appears on the screen or printed page of such transmission.

JSTOR is an independent not-for-profit organization dedicated to and preserving a digital archive of scholarly journals. For more information regarding JSTOR, please contact support@jstor.org. 


\title{
Comment on the Modigliani-Miller Propositions
}

\author{
Stephen A. Ross
}

$\mathbf{W}$ hat a treat it is to have the opportunity to read Merton Miller's ruminations on the MM Propositions. If the view of the progress of science that interprets it as one of changing paradigms has merit, then surely the work of Miller and Modigliani provides a laboratory example of a violently shifted paradigm.

Through Miller's eyes we can recapture some of the flavor of how dramatic that change was. We are now so accustomed to the acceptance of the new paradigm that the older view that capital structure did matter has about it the flavor of phlogiston. Not only does it seem wrong, it is difficult to believe that sensible folk could have held such beliefs. In fact, though, as with phlogiston, not merely did esteemed scholars subscribe to the view that capital structure did matter, the stubborn debate that followed the first publication of the MM papers attests to their devotion.

Because economists now do look at finance through the eyes of $\mathrm{MM}$, one of the contributions of a retrospective appraisal is that it affords us the opportunity to explore what, if anything, there was of value in the older view that we might have lost in our zeal to replace it. This is what Miller emphasizes when he says that "showing what doesn't matter can also show, by implication, what does."

As their work has been recast in the shifting landscape of ever more modern theory, there is a danger that the original analysis will become discarded as "crude" or "naive." This would be a terrible mistake; the older analysis was designed less to verify some mathematical truism than to capture a live and elusive scientific intuition. Since the newer theory rests on a somewhat different base of intuitions, some of the older insights embedded in the original proofs and analysis may be lost. Miller's piece provides an opportunity to do some excavating.

- Stephen A. Ross is Sterling Professor of Economics and Finance, Yale School of Organization and Management, Yale University, New Haven, Connecticut. 
A comment on Miller and Modigliani's work can easily become a discussion of any facet of modern finance. To avoid overlapping unnecessarily with the other comments, I will focus my dig in the two areas of arbitrage and taxation.

\section{Arbitrage Analysis}

Since the original MM analysis economists have learned an enormous amount about the role played by no arbitrage conditions in financial markets. We have discarded the risk class based arbitrage arguments and no longer have a need for the perfectly correlated companion firm that MM used. Now we merely invoke the result that the absence of arbitrage implies the existence of a linear pricing rule (or, equivalently, an expectation) that can be used to value all assets as a function of their payouts (or their expected payouts using risk adjusted probabilities). ${ }^{1}$

To illustrate the new analysis, consider the typical firm whose total value is equal to the sum of the values of its debt and its equity. The values of debt and equity, in turn, are based on the cash flows that are expected to go to each. Since the cash flow of the firm must go either to debt or to equity and since linearity assures us that the sum of their values is the value of the sum of their cash flows, it follows that the total value of the firm depends simply on the total cash flow of the firm, regardless of the debt-equity mix chosen by that particular firm.

But have we really learned that much? And if we have, what do we now know about the original MM proofs? The original arguments went something like this. Imagine two firms in the same risk class; in particular, assume that they have identical cash flows. Suppose that one is capitalized with equity alone and that the other has both debt and equity outstanding. Lastly, suppose that the levered firm's value is less than that of the unlevered firm.

Purchasing an equal percentage share of the levered firm's debt and equity would then cost less than the same percentage share of the all equity firm, but it would entitle an outside investor to exactly the same cash flow. Such an arbitrage possibility would raise the price of the levered firm's equity and lower that of the unlevered firm until the two firms had the same value.

Conversely, if the levered firm were relatively overvalued, then by combining the unlevered firm's equity with borrowing - that is, by creating "homemade leverage" - the investor could duplicate the return on the levered firm's equity at lower cost. Of course, this scenario raises questions about the ability of investors to borrow on their own accounts as cheaply as the levered firm.

What happens to the features of these arguments when we bring in the deux machina of modern arbitrage pricing analysis? For one thing, we do away with the need for a replicating firm in the same risk class. The risk class argument is a way of making the point that in cross section the firm will not alter its value by altering its capitalization. It is a subtle device. When a firm changes its capitalization this has

\footnotetext{
${ }^{1}$ Varian (1987) and Dybvig and Ross (1987) provide introductions to the modern no-arbitrage analysis.
} 
potential effects on the entire financial equilibrium. This, in turn, clouds the analysis immeasurably by taking it into the realm of general equilibrium where the action has rippling effects on prices and actions throughout the economy. The replicating firm is a device for eliminating this problem and confining the argument to a partial equilibrium. As long as two identical firms coexist, they cannot differ in value.

The modern arbitrage analysis, while it hides some of the machinery of arbitrage, repays us by making this point more explicit. As long as changing the firm's capitalization does not alter the pricing of risky cash flows in the economy as a whole, then changing the firm's capitalization cannot alter its value.

However, strictly speaking, this is not what the MM arguments prove. Rather, they only show that within their risk class relative values are unaffected by capitalization. There is nothing in their arguments that would preclude the firm from changing its capitalization and raising or lowering the value of both itself and the unlevered firm. In other words, strictly speaking, the original analysis really only works when the unlevered firm's value is pegged. But this is just an implication of the assumption that the economy wide pricing of cash flow streams is unaltered.

This takes us back full circle to the original Marshallian and neoclassical analysis of perfectly competitive markets with constant returns to scale. The supply curve is perfectly elastic in such a market because the expansion of any one firm's output can be accommodated by an equivalent contraction in the output of the other firms. Since equilibrium profits are zero the real equilibrium is unaltered.

Similarly, when one firm raises its debt-equity ratio, its value is unaltered because the pattern of risky cash flows that it is supplying to the capital market can be duplicated elsewhere in the economy at no cost. If this picture of the world seems a bit farfetched, one might be tempted to succumb to pragmatism and simply rely on the intuition that the change would, at most, have a small effect, but there is merit in the pristine certainty of the neoclassical world.

In either case, the richness of substitutes for the cash flows offered by any one firm now takes the place of the identical firms in the original MM risk classes. Depending on the pricing rule for the economy, this is a truly meaningful extension. For example, unpriced idiosyncratic risk can imply that even if the random characteristics of a firm's cash flows differ dramatically from those of other firms in the economy, nevertheless the idiosyncratic component of the cash flow will be valueless and will not affect the substitutability or the pricing of the firm (although it will influence the relative pricing of the debt and the equity).

The argument is the familiar one from insurance. Two similarly situated individuals will pay the same for life insurance not because their deaths will be perfectly synchronized but, rather, because they are independent. As a consequence, at the margin they contribute nothing to the risk of a large pool and can receive "fair" insurance. The same pooling of independent risks occurs in the financial markets and two securities can be perfect substitutes in large portfolios even if they are quite different. Indeed, we can now replace the two identical firms in the MM arbitrage argument with two firms with the same value and with completely uncorrelated cash flows. 


\section{The Concept of a Risk Class}

This process of understanding how the economy allows investors to duplicate the risky return of any individual company should be understood as an expansion of the original MM notion of a risk class. The "risk class" played an important role in the original arbitrage analysis, as Miller explains, but it has subsequently passed from favor. However, I think that it might be time for a revival of a modern perspective on the older views. This is particularly so given the sorry empirical state of our asset pricing theories.

As I have argued, Miller adopts too narrow a view of a risk class when he refers to it as a "spanning set" consisting of firms such that "the uncertain, underlying future cash flow streams of the firms within each class could be assumed perfectly correlated, and hence substitutes." To some extent this limited interpretation may be responsible for the atrophied interest in the concept.

Two cash flow streams that are perfectly correlated differ only by a sure cash flow and a difference in scaling. From the perspective of the pricing of risky assets they are essentially identical. This is the same identity that underlies modern option pricing theory, but the intuitive appeal of the notion of a risk class is broader than the observation that two identical cash flows must have the same value.

Presumably the concept has merit because a risk class can be defined under less stringent requirements; that is, two cash flow streams need not be perfectly correlated to be meaningfully placed in the same risk class. If an implication of being in the same risk class is that securities have the same cost of capital, then, since the cost of capital depends on the systematic risk of a company, we have seen that two firms with completely uncorrelated risks, risks that are independent of the major systematic risks in the economy, can be placed in the same risk class.

The important possibility opened up by the concept of a risk class is that of arguing on a priori grounds that the structural and financial characteristics of two firms are such that they would respond similarly to exogenous economic shocks and, as such, belong in the same risk class. If this could be done successfully in a cross section analysis of firms, then it would free the question of the determination of the cost of capital from an allegiance to one or another of the competing asset pricing models.

Whether or not such further research on the concept of a risk class will be fruitful has direct implications for empirical work in the MM theory, and to the extent to which such research leads to new insights on the implications of the absence of arbitrage, it bears directly on the theory itself. Miller rightfully considers what might be called the fine structure of the arbitrage arguments. In response to whether individuals could actually implement the homemade leverage he points out the inessential nature of the limited liability assumption and he notes that corporations as well as individuals hold securities and can arbitrage. He also observes the seeming obstacles to arbitrage posed by the special features of common stock such as voting rights. In a sense these make for a different sort of arbitrage and, presumably, a more difficult sort.

But, focusing on these shortcomings of arbitrage arguments seems to me to ignore those very changes in the financial markets to which Miller calls our attention. While 
the range of corporate instruments is not really much more innovative today than it was even a century ago, the range and the volume of trading in noncorporate securities-including securities such as call options that, while not issued by corporations, are derivative to them-has increased exponentially.

This means that the major force of arbitrage appears less at the firm level than it does within the capital market itself. The number of close substitutes for any security is now so deep and rich that any corporate security can now be priced by arbitrage. To put it in terms of our previous discussion, we need only find the security's risk class.

\section{Arbitrage and Taxation}

Taxation is where the real world meets the theory. At first blush, the corporate deduction for interest seemed to doom the MM analysis to an academic curiosity, since it appeared to give debt an obvious cost advantage over equity. It was the genius of Miller to see that the arbitrage analysis went much too deeply into the workings of the financial markets and the economy as a whole to be easily unseated by even something as powerful as the tax code.

Although the original MM papers dealt with this issue, it surely reached maturity in Miller's (1977) seminal paper on debt and taxes, a paper which should be thought of as a companion piece to the original MM papers. (See, also, previous work on these matters by King (1974) and Stiglitz (1973).) Miller acknowledged that the corporation would enjoy higher total after-tax income by increasing its debt-equity ratio, and that this additional income would also result in a higher gross combined payout to stockholders and bondholders. But his tactic did not mean that the value of the firm would have to increase. As debt is substituted for equity, the proportion of the payout in the form of interest on the debt rises relative to the payouts of dividends and capital gains on equity. To the extent that investors are relatively more heavily taxed on interest payments than on equity returns, this cuts into the corporate advantage to the issuance of debt.

From the perspective of the corporation, debt now costs more relative to equity than it did, with the wedge between them equalling the marginal investor tax advantage of equity over debt. Miller further showed that with a rising marginal tax rate for investors, a sensible equilibrium would be one in which the corporate cost of equity was below that of debt by precisely the marginal corporate tax advantage of debt.

Of course, as Miller points out again in his comment, this logic does not imply that the aggregate issuance of corporate debt need be indeterminate. In fact, his equilibrium provides a unique solution for the proportion of corporate debt outstanding. Once this equilibrium is reached no corporation would see a tax advantage to the issuance of debt and the original irrelevance proposition would be restored. As Miller also noted, though, there would not be an internal equilibrium if the wedge between the personal tax on interest income and that on capital gains was too small relative to the corporate tax rate. In fact, back of the envelope calculations, particularly with the 
recent changes in the tax code, reveal that the personal advantage to receiving capital gains is too low to compensate for the corporate tax. ${ }^{2}$

Without the offsetting effects from the personal tax code, the only brake to the expansion of firm debt would be the recontracting costs implicit in bankruptcy. Since the costs of bankruptcy seem relatively small in comparison with the tax advantages of corporate debt, it is difficult to explain the relatively conservative debt policies of many corporations. This is exacerbated by the possibility of income bonds and other devices for minimizing the bankruptcy potential while retaining the tax advantage. Leveraged buyouts and other vehicles for creating explicitly risky debt cum control rights are a more recent approach to the same problem.

These insights put academic economists in the awkward position of finding corporate America unwilling to take some rather obvious actions to maximize value. As Miller notes, this is not very comforting for advocates of positive economics. Perhaps to ease their burden, at the end of his comment Miller alludes to an infinity of ways by which business can avoid or lessen the impact of the double tax hit on corporate income. Ross (1985) explores some of these possibilities, and it is here that I find the true lesson of the intuition behind the MM propositions and the absence of arbitrage.

I would like to conclude by offering a modest if extreme version of this intuition. The mathematician, Godel, argued that no finite set of axioms for mathematics could ever be sufficient in the sense that there would always remain undecidable propositions that could be added or not without affecting the integrity of the original system. It seems to me that the time has now come to marry Godel and the IRS with MM presiding at the ceremony. To wit, we now have an explanation for the secular expansion in the size of the tax code:

Godel and Miller's Tax Proposition: No finite and feasible system of business taxation can collect positive revenues.

Feasible just means that no one is required to pay more taxes than they have. In a world of less than perfect information and expectations the tax code grows as the government tries to plug the loopholes that continually arise out of the inability to specify all of the possible contingencies and the groping by business to avoid taxation. (In the process the corporate tax does seem to raise a good piece of change.)

Proving this proposition is more difficult than stating it, but perhaps the modern combination of the no arbitrage analysis with the tax code provides a clue. To begin with, we know from the no arbitrage analysis that the value of a firm's income is a function not only of the total cash flow but also of the forms in which it comes packaged, including depreciation offsets, capital gains, and so on (see Ross, 1987). Given a price for each of these, the firm will package itself so as to maximize its value.

\footnotetext{
${ }^{2}$ Even the personal tax effect is not determinate and, depending on the code and other features of the economy, very different equilibria are possible. In some, the corporate gains from leverage dominate and maximal debt is optimal; in others, the gains are actually losses and firms retreat to all equity.
} 
Ignoring organizational costs, firms will then combine, split and reorganize into entities with different tax rules in such a way as to minimize the tax.

While our conjecture doesn't quite merit the usual Q.E.D., it does serve to illustrate a proposition that surely does. Namely, that economists owe a debt to Miller and Modigliani that is at least as great as that which mathematicians and philosophers owe to Godel. ${ }^{3}$

- The author is grateful to the editors, Carl Shapiro, Joseph Stiglitz, and Timothy Taylor, for their helpful comments.

${ }^{3}$ Or is it equity? Well, it doesn't really matter, does it?

\section{References}

King, Mervyn A., Public policy and the Corporation. London: Chapman \& Hall, 1977.

Miller, Merton H., "Debt and Taxes," Journal of Finance, May 1977, 32:2, 261-75.

Ross, Stephen A., "Debt and Taxes and Uncertainty," Journal of Finance, July 1985, 60:3, 637-57.

Ross, Stephen A., "Arbitrage and Martingales with Taxation," Joumal of Political Economy, April 1987, 95:2, 371-92.

Dybvig Philip H., and Stephen A. Ross, “Arbi- trage." In Eatwell J., M. Milgate and P. Newman, eds. New Palgrave, A Dictionary of Economics. London: The MacMillan Press, Ltd. 1987, I, 100-106.

Stiglitz, Joseph E., "Taxation, Corporate Financial Policy and the Cost of capital," Joumal of Public Economics, February 1973, 2:1, 1-34.

Varian, Hal, "The Arbitrage Principle in Financial Economics," The Journal of Economic Perspectives, Fall 1987, 1:2, 55-72. 
http://www.jstor.org

\title{
LINKED CITATIONS
}

- Page 1 of 2 -

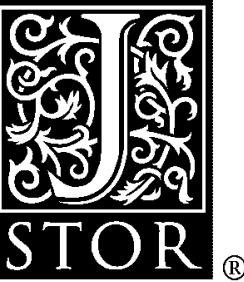

You have printed the following article:

\section{Comment on the Modigliani-Miller Propositions}

Stephen A. Ross

The Journal of Economic Perspectives, Vol. 2, No. 4. (Autumn, 1988), pp. 127-133.

Stable URL:

http://links.jstor.org/sici?sici=0895-3309\%28198823\%292\%3A4\%3C127\%3ACOTMP\%3E2.0.CO\%3B2-2

This article references the following linked citations. If you are trying to access articles from an off-campus location, you may be required to first logon via your library web site to access JSTOR. Please visit your library's website or contact a librarian to learn about options for remote access to JSTOR.

\section{[Footnotes]}

\author{
${ }^{1}$ The Arbitrage Principle in Financial Economics \\ Hal R. Varian \\ The Journal of Economic Perspectives, Vol. 1, No. 2. (Autumn, 1987), pp. 55-72. \\ Stable URL: \\ http://links.jstor.org/sici?sici=0895-3309\%28198723\%291\%3A2\%3C55\%3ATAPIFE\%3E2.0.CO\%3B2-Y
}

\section{References}

\section{Debt and Taxes}

Merton H. Miller

The Journal of Finance, Vol. 32, No. 2, Papers and Proceedings of the Thirty-Fifth Annual Meeting of the American Finance Association, Atlantic City, New Jersey, September 16-18, 1976. (May, 1977), pp. 261-275.

Stable URL:

http://links.jstor.org/sici?sici=0022-1082\%28197705\%2932\%3A2\%3C261\%3ADAT\%3E2.0.CO\%3B2-D

\section{Debt and Taxes and Uncertainty}

Stephen A. Ross

The Journal of Finance, Vol. 40, No. 3, Papers and Proceedings of the Forty-Third Annual Meeting American Finance Association, Dallas, Texas, December 28-30, 1984. (Jul., 1985), pp. 637-657. Stable URL:

http://links.jstor.org/sici?sici=0022-1082\%28198507\%2940\%3A3\%3C637\%3ADATAU\%3E2.0.CO\%3B2-X

NOTE: The reference numbering from the original has been maintained in this citation list. 
http://www.jstor.org

\section{LINKED CITATIONS \\ - Page 2 of 2 -}

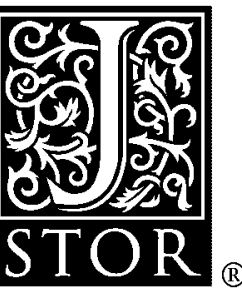

\section{Arbitrage and Martingales with Taxation}

Stephen A. Ross

The Journal of Political Economy, Vol. 95, No. 2. (Apr., 1987), pp. 371-393.

Stable URL:

http://links.jstor.org/sici?sici=0022-3808\%28198704\%2995\%3A2\%3C371\%3AAAMWT\%3E2.0.CO\%3B2-F

\section{The Arbitrage Principle in Financial Economics}

Hal R. Varian

The Journal of Economic Perspectives, Vol. 1, No. 2. (Autumn, 1987), pp. 55-72.

Stable URL:

http://links.jstor.org/sici?sici=0895-3309\%28198723\%291\%3A2\%3C55\%3ATAPIFE\%3E2.0.CO\%3B2-Y

NOTE: The reference numbering from the original has been maintained in this citation list. 